\title{
Okresy odpoczynku a naruszenie dóbr osobistych pracownika
}

\section{Rest periods and infringement of employee's personal interests}

\author{
dr hab. Piotr Prusinowski \\ Uniwersytet Warmińsko-Mazurski w Olsztynie, Wydział Prawa i Administracji \\ ORCID: 0000-0002-5805-9908 \\ e-mail: piotr.prusinowski@uwm.edu.pl
}

\begin{abstract}
Streszczenie Naruszenie dobowego lub tygodniowego okresu odpoczynku postrzegane jest jako uchybienie dobrom osobistym. Problem w tym, że gwarancje z art. 132 i 133 k.p. nie zostały skutecznie zabezpieczone. Odpowiedzialność karna (za wykroczenie) nie jest efektywna. Wobec konieczności wykazania szkody nieskuteczna okazuje się również odpowiedzialność deliktowa lub kontraktowa. W rezultacie, najprościej egzekwować przekroczenie normatywnych okresów odpoczynku przez odwołanie się do art. 24 § 1 k.c. w związku z art. 448 k.c. Zadośćuczynienie za naruszenie dóbr osobistych warunkowane jest jednak funkcją kompensacyjną, a ta nie daje się pogodzić z potrzebą sankcjonowania naruszenia okresów odpoczynku. Na tym tle w orzecznictwie może dochodzić do nieprawidłowości.
\end{abstract}

Słowa kluczowe: okres odpoczynku, urlop wypoczynkowy, zadośćuczynienie, pracownik, dobro osobiste.

Summary Violation of a daily or weekly rest period is perceived as a breach of personal interests. The problem is that the guarantees provided for in Articles 132 and 133 of the Labour Code have not been properly secured. Criminal liability (for an offence) is not effective. Since it is necessary to show the damage, tort or contractual liability also prove to be ineffective. As a consequence, the simplest way to enforce the exceedance of normative rest periods is to refer to Article $24 \S 1$ of the Civil Code in connection with Article 448 of the Civil Code. Compensation for the infringement of personal interests, however, is conditioned by the compensatory function, which is incompatible with the need to sanction the infringement of rest periods. Such a background may give rise to irregularities in the case-law.

Keywords: rest period, annual leave, compensation, employee, personal interests.

JEL: K31

Str. 40-44

\section{Bibliografia}

Driczinski, S. (2006). Glosa do wyroku Sądu Najwyższego z 23 czerwca 2005 r. (II PK 265/04) w sprawie zaliczania poszczególnych okresów po- dróży służbowej do czasu pracy. Praca i Zabezpieczenie Spoteczne, (7).

Jankowiak, J. (2011). Glosa do wyroku SN z dnia 18 sierpnia 2010 r., II PK 228/09. Orzecznictwo Sądów Polskich, (9).

Jaśkowski, K. Maniewska, E. (2006). Kodeks pracy. Komentarz. Kraków.

Kubot, Z. (2007). Dni wolne od pracy za dyżury medyczne. Praca i Zabezpieczenie Spoleczne, (11).

Kubot, Z. (2008). Specyfika dyżurów medycznych. Praca i Zabezpieczenie Społeczne, (1).

Kulig, K. (2015). Prawo pracownika do odpoczynku dobowego. Praca i Zabezpieczenie Spoteczne, (2).

Lewandowski, H. (2008). Dyżur medyczny — uwagi na kanwie wyroku Sądu Najwyższego z 6 czerwca 2002 r., I PK 263/05. Monitor Prawa Pracy, (1). Liszcz, T. (2007). Ochrona prywatności pracownika w relacjach z pracodawcą. Monitor Prawa Pracy, (1).

Rycak, M. (2017). Czas pracy a ochrona życia rodzinnego pracowników. W: M. Szabłowska-Juchniewicz, B. Rutkowska,

A. Napiórkowska (red.), Tendencje rozwojowe indywidualnego i zbiorowego prawa pracy. Księga Jubileuszowa Profesora Grzegorza Goździewicza. Toruń.

Sobczyk, A. (2010). Glosa do uchwały SN z dnia 3 czerwca 2008 r. Orzecznictwo Sądów Polskich, (4).

Samol, S. (2005). Glosa do wyroku SN z dnia 23 czerwca 2005 r., II PK 265/04. Orzecznictwo Sądów Polskich, (11).

Stefański, K. (2006). Okresy odpoczynku w kodeksie pracy. Praca i Zabezpieczenie Społeczne, (1).

Stefański, K. (2013). Czas pracy. Warszawa.

Szewczyk, H. (2018). Klauzula opt-out a ochrona życia i zdrowia pracowników wykonujących zawody medyczne. W: T. Kuczyński, 
PRACA I ZABEZPIECZENIE SPOŁECZNE NR 4/2019 • LABOUR AND SOCIAL SECURITY JOURNAL NO. 4/2019 ISSN 0032-6186 t. LX DOI 10.33226/0032-6186.2019.4.5

A. Jabłoński (red.), Prawo pracy i prawo zabezpieczenia spotecznego. Teraźniejszość i przyszlość. Księga Jubileuszowa Profesora Zdzisława Kubota. Warszawa.

Wujczyk, M. (2012). Prawo pracownika do ochrony prywatności. Warszawa. 